\title{
Activating the worker in elderly care: A technique and tactics of invitation
}

\author{
Andreas Fejes and Katherine Nicoll
}

\section{Linköping University Post Print}

N.B.: When citing this work, cite the original article.

This is an electronic version of an article published in:

Andreas Fejes and Katherine Nicoll, Activating the worker in elderly care: A technique and tactics of invitation, 2011, Studies in Continuing Education, (333), 3, 235-249.

Studies in Continuing Education is available online at informaworld ${ }^{\mathrm{TM}}$ :

http://dx.doi.org/10.1080/0158037X.2010.549120

Copyright: Taylor \& Francis (Routledge)

http://www.routledge.com/

Postprint available at: Linköping University Electronic Press

http://urn.kb.se/resolve?urn=urn:nbn:se:liu:diva-63293 


\title{
Activating the worker in elderly care: a technique and tactics of invitation Andreas Fejes and Katherine Nicoll
}

Linköping University, University of Stirling

andreas.fejes@liu.se, katherine.nicoll@stir.ac.uk

\begin{abstract}
Relatively little attention has been paid to questions of how language acts in and through the interactions of language in situations where people are encouraged to learn to be active in contexts of work. This paper argues that detailed analysis is needed to understand how activation through language acts in the shaping and governing of workers. By combining resources from Michel Foucault and the conversation analysis of Jonathan Potter, we analyse observational notes and records of conversation from work activities at a nursing home for elderly people in Sweden. A technique and tactics of invitation are identified as operating through language interactions at work in attempts at the shaping of activate and responsibilise workers. This analysis contributes to wider discussions over how attempts are made to shape subjectivities at work.
\end{abstract}

Keywords: Activation, Conversation analysis, Elderly Care, Foucault, Governing, Organisational Management, Rhetoric

\section{Introduction}

European and national policies on education and employment argue that workers must become more active if they are to contribute more fully to economic growth (European Commission 2001; Ministry of Social Affairs 2007; Berkel and Borghi 2007). Policies are written in ideal terms and suggest that all will benefit. This kind of ideal for the active worker emerges in the human resource development literature (cf. Townley 1993a; 1994) where such descriptions have been problematized by research inspired by the work of Foucault. Here, the relation between the manager and the employee is identified as having changed over the last years, with the focus increasingly on techniques that activate employees and make them responsible for development and learning (Rose 1996; 1999a; du Gay 1995; Fejes 2010a; b). The techniques used for activation are different in different contexts. For example, prospective employees learn how to narrate themselves as active subjects in writing a CV (Metcalfe 1992) and once in work employees are positioned as responsible for work development (Townley 1993b; 1994; 1996), through, for example, performance appraisals (Townley 1993a) and teamwork (Sewell 2005; Knights and McCabe 2003). Employees may even be required to position themselves as loving their organization (Andersen and Born 2008). An ideal of activation is then part of a wider politics that shifts responsibility for action to the individual and requires specific techniques to encourage this (Dahlstedt 2009). These are techniques through which workers should learn who to be and how to act to be effective. They are techniques that attempt to shape and govern worker subjectivity (cf. Fejes and Nicoll 2008; Foucault 2007; Nicoll 2008; Collinson 2003).

In this paper we turn attention to the regime of practice governing elderly-care, which in Sweden is reorganized through policy arguments for the active worker and discourses of new public management (NPM). Such discourses introduce new ways of organizing elderly care and specific ways to speak about and describe care. 'Activation' is seen in this paper as a technology that operates through language with the intention of shaping and fostering subjectivity (Foucault 2007). A technology mobilises specific techniques and tactics in order to reach its goals (Foucault 2007; Potter 1996). In our examples and analysis we show that the manager mobilises a technique of what we characterise as that of 'invitation', together with 
rhetorical tactics that are part of her communications of language aimed at the activation of workers. By analysing these, it is possible to identify how versions of reality are achieved in description (Potter, 1996). For our analysis we focus specifically on the language interactions between a manager and her workers in an elderly-care home, based on records of conversation and notes of observations. An elderly-care worker research project conducted by Fejes (2008; 2010a; 2010b; Fejes and Nicoll 2010) and focused on workplace learning and the constitution of subjects, allowed for detailed examination of what goes on in attempts in the production of the active subject through language interactions between the manager and her workers. It is thus to the way that language operates in these sort of attempts that our exploration and theorization turns.

If we turn to previous research, relatively little attention has been paid to questions of what actually happens through the interactions of language in situations where workers are encouraged to learn to be active at work. From an analytics of power perspective informed by the work of Michel Foucault (2007) we argue that much research on workplace learning (cf. Boud et al 2006; Johns 2000) tends to support the constitution of the active subject within systems of governance. Such research functions to develop knowledge of techniques that activate the worker, and understandings of how these could be best integrated into work or learning practices. This is research in the development of knowledge of the 'what' and 'how' of power through what techniques could power operate? and, how might they be made (more) successful? A potentially critical and diagnostic form of research provides alternatives (cf. the work of Townley above; Rose 1999a). This second category is concerned to explore the means by which power is exercised in practices of activation, through the identification of mechanisms and procedures, technologies and techniques and examination of power effects. This category draws on Foucault's writing on governmentality and power to explore the means through which people are positioned as activated workers. However, there has been little attention to the work of language in this category. This is a question of the way in which governing is attempted through language, and how subjects are encouraged to position themselves in particular ways. As Hollway (2001, p. 277) argues:

Discourses make available positions for subjects to take up. These positions are in relation to other people. Like the subject and the object of a sentence... [people are] placed in relation to each other through the meaning which a particular discourse makes available.

To understand how specific techniques and tactics for activation operate through the language of the workplace more detailed forensic analysis is needed. This paper combines resources from the work of Foucault (2007) and later theorists Dean (1999) and Rose (1999a) with those from the conversation analysis of Potter (1996) for one such analysis.

The paper is in six parts with a conclusion. In the first, we identify a concern with professionalization as part of a discourse of new public management in Sweden, marking a turn to a consumer-oriented approach in the public sector. These are elements in the regime of practice of care and thus important if we are to understand how current discourses of activation operate within a wider regime of power. In the second part, we introduce our analytical perspective and raise some issues regarding methods. The third part identifies empirical material as data from field work and the form of data analysis used. From the fourth and fifth parts, we present some examples and analysis of these. Here we illustrate how the manager at the home mobilises a specific technique and rhetorical tactics of language that work to position employees as active and responsible. Thus, we identify and illustrate the work of rhetoric in attempts 
to constitute the activity of workers. These tactics emerge as regularities in data that has been analysed and are illustrated here. Lastly, we discuss our finding and outline our conclusions.

\section{New public management and professionalization}

During the last two decades there has been a shift in the governance of elderly care in Sweden and more broadly. A discourse of NPM mobilises a reorganization of public services and the identities of workers (cf. Dahl 2009). Although NPM is often spoken of as if it has coherent and homogeneous meaning, critical feminist research has illustrated how it is dynamic and taken up differently depending on who speaks where (cf. Dahl 2009; Thomas and Davies 2005). In Sweden, the discourse takes up a purchaser-provider model that was introduced in elderly-care in the early 1990s (see Hebson et al, 2003, in the UK). The policy argument was to increase the number of workers in the elderly-care market, with the intention of making work more effective at lower costs. This was combined with no or little investment in training for employees. The assumption was that training workers to the new circumstances could be carried out during work hours (Ellström et al. 2008).

Lately, a discourse of professionalization has become tied to that of NPM, supporting the reorganization of elderly-care work in Sweden. Policy makers stress that there is an increasingly ageing population and the availability of public funding for care for the elderly is effectively decreasing. Swedish policies argue that there will be a lack of 200,000 health care workers in elderly care and home care for disabled people in year the 2015 unless measures are taken to make such work more attractive. By raising the competence level of those already employed it is hoped that there will be improved care and better preparedness for the advanced needs of residents in the future (Ministry of Social Affairs 2007). Such policies are aimed at activating workers and making them responsible for work (cf. Fejes 2010a).

Similar arguments are used in other Nordic countries (see Henriksson 2010 for the case of Finland) and in the UK (Entwistle, et al. 2007; Kubiak 2010). They are related to broader shifts towards consumer-orientation in the public sector. Here a revised professionalism is part of new public management and not in tension with it (Theodosius 2008). Wider shifts in policy discourses and practices across the nations of the West support a quite general reconfiguration of the regime of practice that governs elderly-care work and attempts the activation of care workers. This is not to suggest any simple linear cause-effect relationship between policy dictate and the activation of workers, nor to suggest that subjectivities are determined through policy. Subjects always have the possibility of acting otherwise than the strategies of a regime of practice articulate. Techniques and tactics are however being reconfigured with the activation of workers as the goal. What these are, and how they operate is thus important to explore empirically and in some detail.

\section{Technologies and techniques of activation}

We draw on resources from the work of Michel Foucault (2007), Mitchell Dean (1999), Nikolas Rose (1999a) and Jonathan Potter (1996) for our theorization of a technology of activation and rhetorical technique and tactics of invitation within a regime of practice. 'Practice' here signifies something quite different from an everyday understanding of it, as it is bound in a relationship between power, truth ('true' knowledge) and identity. Practice is the organized and routinized ways we do things that become stabilized as a regime of practice (cf. Dean 1999). A regime of practice operates in part through the ways that things are done within workplaces and institutions. It may be identified in elements that are linked and most densely focused and coordinated within and through institutional practices although it is not equivalent to them. Language operates in such practices (cf. Rose 1999a). In examining how lan- 
guage is linked to knowledge and embedded in the means for shaping conduct we can gain a wider understanding of how we are governed through knowledge and govern ourselves. Thus, we can begin to explore how power is exercised in order that subjects may be shaped. A practice cannot therefore be reduced to an action. It brings together all those actions, language, knowledge and ideals that make up the organized ways we do things.

An analysis of a regime of practice at a general level includes several foci (Dean 1999). First, it focuses on elements that constitute the regime of practice and processes by which these are brought together. Second, on identifying specific knowledge, made possible through this regime and necessary for it to emerge. Third, analysis focuses on technologies and techniques through which the regime operates and reaches its goals. It is the last two foci that we emphasise in the ensuing analysis. We illustrate how the manager at the home 'invites' as a technique that works to activate employees in particular ways and positions them as responsible. We focus, then on this technique and rhetorical tactics as part of a wider technology of activation and as they operate in the exercise of power.

A technology does not have an essence, nor is it the outcome of a specific will or intention to govern (Rose 1999a; Fejes and Nicoll 2008). Rather, it is an assemblage of elements that come together tactically and aspire to shape specific subjectivities (Rose 1999a). The confessional technology is one such assemblage; one that has become central to the exercise of power across the Western world in part through processes and techniques of learning (Foucault 2007). Technologies depend upon such specific techniques and tactics in the shaping of subjectivities. For example, performance appraisal is a technique within a wider confessional technology (Fejes 2008). Here the employee becomes object of knowledge (visible for calculation) and is made subject as a particular kind of employee through a process whereby he or she comes to know and act on the soul (cf. Rose 1999b). It is a technique and tactics as they operate through language that we identify and focus on here in the activation of workers in elderly-care.

We turn to resources from Potter's (1996) conversation analysis for methods from the study of rhetoric to explore means for attempts at the shaping of worker subjectivity. To combine analytic resources from the work of Foucault and a rhetorical analysis has been useful. Language acts - it builds versions of reality: 'Conversation analysis provides the final story of how fact construction gets done' (Potter 1996, p. 102). Here we have not been concerned with everyday 'talk-in-interaction', but with wider regularities - 'talk and texts as parts of social practices' (Potter 1996, p. 105). The focus has been on the means by which language acts through rhetorical tactics.

Rhetoric is not confined to communication that is designed to persuade but is an intrinsic part of the way that language works through description to build up pictures of 'reality'. Policies, workplaces and sites of learning are suffused and enmeshed with competing attempts to build up 'factual' and 'correct' pictures through language. Indeed, any 'education, like so many aspects of human endeavour, is inherently a rhetorical practice' (Edwards et al. 2004, p. 3). Potter (1996, p. 108) argues that descriptions of reality are antagonistic in the way in which they work to act: 'Put at its simplest, one of the features of any description is that it counters, actually or potentially, a range of competing alternative descriptions...'. Potter suggests that any factual account can be examined for the way in which reality is built up and other potential descriptions countered. 'The concern can therefore be with descriptions and representations as they are built in the course of interaction;... not... to notional, in-the-head entities such as perceptions or representations...' (Potter 1996, p. 104). A rhetorical analysis identifies 
how versions of reality are achieved in description through what we have characterized as rhetorical 'tactics'. And, to the extent that these are relatively commonplace, regular and repeated in the communicative settings, they begin to indicate work of language to build reality, as it is attempted.

\section{Empirical material and analysis}

This paper draws on analysis of field work data (cf. Hammersley and Atkinson 1995) from a study in a nursing home for elderly people in Sweden. This is a home situated in a municipality that drew at the time of the study on the purchaser-provider model that was being promoted through wider discourses of new public management. Workers in this home were thus regularly exposed to business language. One of the authors visited the home on thirteen occasions during a period of eight months. During these visits the work-team at one of the three units in the home was observed over a period of five days. The manager was followed during her work (three days), and, during five visits the staff meetings of two different teams of workers were observed. During observations, field notes were taken where the observer noted what was taking place, what was being said, and how those observed interacted with others. Informal conversations about what was happening took place during observations when the possibility for this emerged. The observations were complemented by semi-structured interviews. In total, eight health care workers and their manager were interviewed, some of them several times during the eight month' period. All interviews except one was tape-recorded and transcribed. On request of the interviewee, one of the interviews was not tape-recorded. Instead, the interviewer took as detailed notes as possible.

Our focus in analysis draws resources from conversation analysis as well as from the Foucauldian post-structuralist discourse analysis that indicated above. A key resource in relation to the former form is its focus on how an account is built as real and what it attempts. Conversation analysis approaches the construction of reality as something that has to be done: 'something that has to be achieved using some devices or techniques' (Potter 1996, p. 102). Potter distinguishes this approach from other forms of language analysis in that while linguistic and post-structural approaches to construction might consider the use of a term or a familiar discourse sufficient for it being taken as real or factual, in conversation analysis reality and factuality require rhetorical devices and techniques specific to that setting. '[R]ealism and factuality are worked up using a set of rhetorical devices and techniques which may be specific to a particular settings' (Potter 1996, p. 102). Potter uses a metaphor of the building yard to distinguish between the post-structuralist and conversation analysis approaches. Whilst discourses are already available as resources (pre-fabricated sections of buildings), devices and techniques are specific to the setting and are what holds the pre-fabricated parts of the building together as a particular building (as bricks and mortar).

We take as key resources for analysis, aspects of both discursive and conversation analytic approaches. That is, that it is both in the wider regularities of and within language interactions between the manager and her workers that discursive regularities emerge. These regularities, identified through discourse analysis can be fruitfully further examined in terms of the specific realities being attempted, and the particular devices and techniques specific to these attempts (conversation analysis). Neither 'reality' nor 'truth' are the focus of this analysis, rather the way in which devices and techniques of language interaction are drawn upon to act to do something in specific settings.

It is important to engage reflexively as researchers in what we are doing here. For, to push the above metaphor further, we cannot avoid using pre-fabricated parts or bricks and mortar to 
build our own descriptions. Leaving the building metaphor behind and thinking of the positioning of the researcher embedded and embodied in discourse, there is no position outside discourse to speak from. Observational notes are descriptions in their own right (as is this text also). There can be no outside discourse in this respect. However, in our attempt to avoid the trap of questions of reality or truth, we also put the question of whether we interpret truthfully aside. Here we focus from our position in discourse, on discourse.

We draw also as resource on a notion of 'serious speech act' (Dreyfus and Rabinow 1982). For a speech act to be serious it is connected into a wider network of discursive relations and regularities of communication that these bring forth. Here we are encompassing regularities of device or technique within as well as between serious speech acts, and as these link to wider elements of discourse. Returning then to the question of positioning in our attempts to build our own serious speech act of these regularities, we hope that these can be accepted within the discursive regime in which 'we' - researcher, writer and reader - are embedded and embodied, even as we attempt to distance ourselves from them. We will then need to leave it up to the reader to judge whether we have been successful.

The next section illustrates and exemplifies a technique of invitation that we identified in the data as operating in and through the regularities of communication between the manager and her staff - in everyday work practices and meetings with staff. We specifically focus on this technique, communication surrounding its deployment and the rhetorical tactics associated with this communication. The names of people have been changed for their anonymity.

\section{A technique of invitation at work}

The manager at the home (Donna) mobilises language. It is through repetition that specific realities may become internalized by employees and action brought forth in particular ways. Thus, we engage with an analysis of constitutive practices that govern through language.

The manager mobilises a technique that we characterize as that of 'invitation' to ask employees to identify solutions and set problems. Detail of this differentiates it from a confessional technique, as it does not invite the subject to direct the gaze inward on the soul (cf. Rose 1999b). A confession invites gaze on the soul and most intimate desires of the subject, fostering a will of disclosure in the shaping of subjectivities (cf. Fejes 2010b). A confessional technique of invitation to speak is here taken up and adapted in a form that invites a technology of the self, constitutive of a positive, new self - one that is knowledgeable rather than confessional. The inward gaze is here directed inward at the 'knowledge' of the self, in the construction of understandings of problems and solutions.

This technique is illustrated here through the following field note. The manager, Donna, has received a phone call from a trustee about one of the residents. The message is constructed as problem that needs solution:

Directly after a phone call from a trustee who wants to have a lamp installed for his resident, Donna walks straight away to the unit to discuss with the care workers how to solve this problem. She asks them - 'how can we solve this?' (Field note from Observation 2)

By asking the care workers this question, Donna mobilises what we characterise as a technique of invitation that aims at activating the worker. She invites them to join her - 'we' - in finding a solution to a problem. This effects a positioning of them as already having ideas for 
solutions. It is a rhetorical tactic that affords as it builds the 'category entitlement' of these workers to have knowledge of solutions. Category entitlement is 'the idea that certain categories of people, in certain contexts, are treated as knowledgeable' (Potter 1996, p. 133). Although some people - such as doctors or lawyers and care workers here - may be treated as knowledgeable in specific instances, category entitlements are also built up and can be undermined in interaction.

Positioning her workers with an entitlement to specific knowledge builds this entitlement and has several interrelated effects. First, it works up the 'reality' of that knowledge. Second, it invites their acceptance of that entitlement and knowledge. Third, it invites them to take up responsibility for solving the problem. Fourth, it invites them to pool their knowledge and work together on finding a solution. We can see how this invitation is taken up by these employees:

After posing the question to the employees, a discussion emerges, while the manager is occupied with a resident. When she returns to the employees she agrees with their suggestion of solution to the problem. (Field note from Observation 2)

This technique of invitation and tactic in affording her workers' category entitlement is effective in that it attempts to activate the workers in a particular way and make them responsible. That the carers respond to the problem that she identifies as a 'reality' is quite likely, given her position as their manager. As we see here they do respond. However, this is not the point of our analysis, as it is the rhetorical work in the attempt to position and mobilize that we are interested in here. By leaving the scene she avoids engagement in the discussion that ensues. This absence avoids in advance any potential undermining of the picture of reality that she has represented. In this move, and in that she agrees with their solution on her return, she positions herself as accepting their authority, knowledge, and judgements in taking this responsibility.

This tactic of affording category entitlement is used again by Donna when she is in conversation with her administrator (Darlene) at the nursing home. Each Wednesday she and her administrator have a meeting concerning staff that have been ill or applied for vacation, and so forth. Here she invites her administrator to elaborate problems as well as solutions. We can see in both the example of invitation with the carers (above) and with Darlene (below) that the technique of invitation acts to bring forth activity. It positions workers as knowledgeable and responsible and affords them category entitlement in this way. It appears on the one hand to be a relationship of trust that is being built - but to suggest this would be to slip into psychological analysis. In this analysis it is what this interaction does in building a specific reality of category entitlement, and how it works to build it that is significant.

In the example below, the aim of the meeting and the interplay that builds and shapes Darlene's action in the interaction is revealing:

Donna and Darlene have a meeting concerning the staff situation and about how the employees handle the organization of their days off. The meeting is a bit slow, but then Donna takes charge by asking questions of Darlene. According to Darlene, work team A only has one person who will have time off during Christmas, she thinks that work team B need to be better at planning their work days - 'They should be able to finish by half-past two during the day'. Donna agrees with this, and says that they should therefore keep those times! (Field note from Observation 5) 
The administrator is positioned with category entitlement to specific knowledge of other employees and responsibility over judging how to best organize them. This invitation is steered this time through Donna's questioning. This technique of invitation through steered questioning, attempts an internalizing of the exercise of power. The administrator is invited to work on her knowledge, and herself, to activate and regulate herself through the interaction.

The manager identifies her workers in the data quite regularly as 'co-worker'. Although the relationship appears non-hierarchical in this naming, her invitations are differentiated according to the level and category of worker that she addresses. In the questioning above, steered by the manager, she elicits a specific internalised activity of problem identification and resolution by the administrator. By accepting her administrator's analysis and solution, Donna positions Darlene as responsible for this process as well as for the solution that she proposes.

The cumulative effect of such regularities may well be the acceptance by the workers of those different category entitlements and in the knowledge of and identification and solving of problems - they may learn to act in this way. At the same time, the differential entitlements organize them all hierarchically, channelling power strategically through their relationships and entitlements to improve the effectiveness of combined activity. The care-workers, on the one hand, are invited to work together to solve problems identified by the manager, and the administrator, on the other, to both identify and resolve problems in organizing them more efficiently. The manager channels the exercise of power, through her invitation and the rhetorical tactic of affording specific differential category entitlements.

\section{A technique of invitation during staff meetings}

Donnas' mobilisation of the technique of invitation is also visible in staff meetings. Every fourth week she holds a meeting with each of the three work groups. During these meetings issues can be raised by carers. Between meetings, the group of carers list issues on a board in their office. During the meeting, the carers' list of issues is added first on the agenda and the manager adds her items last. One of the carers chairs the meeting and another takes notes for minutes. The framing of the meeting itself invites category entitlement to knowledge of issues as they arise in the work of individuals, and their responsibility in this. In the following field note the manager positions herself again as one who asks questions, and invites the carers this time to both define problems and solutions:

A few minutes into one of the meetings with work group B, Donna asks what items the work-group wants to add to the agenda.

Work group member: 'Our work schedule, how we are supposed to have time to do all the tasks. We are afraid to get back the stress we previously had. Now it has been good, but how will it be?'

Donna acknowledges their worries and promises to make a follow up of the new work schedule.

Work group member: 'We don't have time to do what we should as contact persons for some of the residents'.

Donna: 'How do you define your role as contact persons?' 
Work group member: 'To take them for walks. We also do a lot of shopping for them.'

Donna 'Twelve if I'm not mistaken.' She asks them if it is possible to coordinate the shopping.

Work group member: 'Yes, we do. But you can't shop for five to six people at the same time'.

Donna: 'Is five too much?'

Work group member: 'Yes, three is enough if you are by yourself.'

Donna 'Is it possible to do the shopping in another way than you usually do?'

Work group member: 'Shop for all at the same time'

Donna 'Have you looked at how other nursing homes do it? Not everyone is as close to a shop as we are.'

Work group member: 'In home care they have a car.'

Donna 'Maybe it's possible to borrow their car sometimes?'

The discussion continues and at the end Donna summarizes the problem and reflects about how it might be solved. As an observer, I felt that Donna was trying to get the care workers to reflect about solutions to the problem they raised. She agrees both with their definition of problems and solutions. (Field note from Observation 3)

Three distinct and further tactics are important to note here, as they have specific effects. The workers initially identify the work schedule as the problem - they have too much to do in the time available. This is a move of 'externalization', a common rhetorical tactic that acts to construct the problem as a fact in a particular way. It puts the responsibility for the problem outside the agency of the workers accounting for it (Potter 1996). The problem is external to the workers and beyond their agency.

Donna implicitly accepts that if the problem is one of a work schedule, it falls to her to deal with it. She initially appears to accept the 'reality' of this externalization of the problem, through her promise to look into it herself. However, she quickly steers the conversation so that the problem becomes 'internalized' as that of the workers - as able to be solved by their action. This is in part a defensive tactic. It turns worker attention away from their initial externalization and her potential agency in solving the problem, onto themselves and their own work organization as the problem to be solved. It then affords the workers the category entitlement to have knowledge of this problem, and so to find a solution for it. Donna steers the conversation so that a worker analysis of role and job tasks can then unfold into an interrogation of effective action. The worker is positioned as responsible solving the problem of lack of time. 
The worker as 'contact person' is at the same time being built as 'factual', 'real', and able to be categorized in this way. Knowledge of job tasks is called forth and broken down into constituent parts (taking the resident for walks and shopping), and knowledge of the effective organization of one task is worked on.

'Categorization', 'externalization' and 'internalization' are rhetorical tactics commonly used to constitute the reality through descriptions. But they only act in this way insofar as reality is treated as such: 'Formulating as something brings the things into being only in so far as it is understood or treated as such in a particular interaction' (Potter 1996, p. 177, italics original). Where this kind of interaction is repeated, so that problems are internalized by the workers and scrutinized in terms of their better organization of the job tasks of the contact person, this reality is reinforced and workers may come to act in this way.

It is interesting also to note that the category 'contact person' avoids perhaps the more human qualities of relationship - the person is a 'contact', rather than a 'friend', 'carer', 'companion' and so forth. This may help keep the workers' subsequent descriptions of their work free of this kind of qualitative detail. If, by contrast, the worker were called 'carer', then a narrative of care would more naturally flow from this naming. 'Narrative start' is an important and specific rhetorical tactic in building descriptions (Potter 1996). By starting a narrative in a particular way, what follows as description then may appear natural, logical and even quite necessary.

The effect of a tactic that turns the worker's externalized description of the problem into one internalized is powerful. Discussion of the manager's responsibility is avoided and the problem is reframed as one internal to the worker group. We can see this action more clearly perhaps, when we look at the tactics that are quite commonly drawn on to place agency with the facts. A common feature of the rhetorical repertoire allows attribution of 'the data' with agency: 'the results show', 'the data support' and so on (Potter 1996, p. 157). In the care home the reverse is happening. The workers want to attribute the work-schedule with agency, but the manager reverses this move to attribute agency to the workers.

\section{Discussion}

In our exploration of the elderly care home we have not been so interested in considering the implications in terms of elderly care, these particular workers, or indeed in relation to theorization of the wider regime of practice that governs elderly-care work. We have been more interested to explore how language is linked to knowledge and embedded in the means for shaping conduct, in order that we gain a better understanding of how we are governed through knowledge and govern ourselves. At the same time we have wanted to explore the argument that we have been making for further such analysis. Those who follow Foucauldian forms of discourse analysis, ourselves included, have not been interested to explore whether detail in the way in which realism and factuality are constituted can be traced in the detail of the rhetorical devices and techniques that are drawn on in and through the language interactions of specific discursive settings. To focus on such detail, has appeared to us to be important.

It is important to acknowledge the wider discourses and elements that constitute the regime of practice that governs elderly-care. A technology of activation and technique and tactics of invitation as characterized and analysed here are connected to and interrelate with discourses on NPM and professionalization. These discourses provide a language for and ways to reason that make it possible for activation to emerge as technology through specific techniques and tactics. For example, as a specific tactic related to a consumer-oriented approach in the public 
sector (Theodosius 2008), as illustrated in Sweden in the purchase-provider model, is a discursive element that makes it possible to speak about the relation between the elderly person and carers as one of business. The elderly person and carer are able to be constituted as a particular kinds of 'objects' - that of a 'client', and the care worker (here) a 'contact person'. This is quite different from speaking about the care worker as a 'carer', which would make space for a very different description of work. How workers are identified as objects therefore matters in the kinds of realities that they make possible as job descriptions. Or, as a further examples, the increased demand on formal qualifications for employees, as offered through inservice training programmes, makes it possible to speak about carers as those who participate actively in these programmes, or not (Fejes 2010a), or those who are competent (those who participate) and those who are not (those who do not participate) (Fejes 2008).

Here we have attempted an analysis that explores 'differences in what is said, how it is said, and what allows it to be said and to have effectivity' (Rose 1999a, p. 57). Through her technique of invitation the manager elicits and fosters workers as active subjects. She is not forcing the employees to act, rather she is inviting them to choose. This technique of invitation is mobilized in our data at times at work and during meetings. Through the language of the manager, specific forms of category entitlement, knowledge, agency, inter-relationship and responsibility are however regularly built up in descriptions and through this attempts at the constitution of a specific worker attempted - invited. Specific rhetorical tactics are used by this manager to do this work in the building of worker reality. Through steered conversations she works to internalize problems so that the worker has agency over them. She invites workers to accept responsibility for identifying and solving these. She steers them to take up category entitlements to work on their knowledge and themselves. She orders them as individuals and groups and ranks them into hierarchical relationships, in order that they may make different forms of judgements and decisions and organize themselves effectively by acting on each other. Subjectification is encouraged in part through the rhetorical work of language that are no doubt connected to wider organizational discourses, but through very specific techniques and tactics.

\section{Conclusion}

Relatively little attention has been paid to questions of what is rhetorically attempted through the interactions of language in situations where workers learn to be active in contexts of work. This is a question of means by which learning takes place through language. We have argued that more detailed analysis is needed to understand how specific techniques and tactics for activation operate in the shaping and governing of workers.

By combining resources from Foucault and Potter we have illustrated some detail of the work of rhetoric in shaping and fostering responsible, activated subjectivities through the interactions of language of a workplace. This contributes to wider discussions over how subjectivity is shaped at work (cf. Barratt 2002; 2003; 2008; Boud and Garrick 1999; Solomon et al. 2006; Rooney and Solomon 2006; Townley 1993a; 1994; 1996). We have illustrated that analysis of the sorts of rhetorical procedures for constructing and managing interactions as they play out in language may be fruitful for exploring the activation of subjects. This, as has been illustrated, could be argued as a form of workplace learning, through which the worker/learner acts in the constitution of situated knowledge, and adopts category entitlement and responsibility to speak knowledgeably of problems and solutions.

Put rather simplistically, the human resource development literature functions dominantly to construct formal knowledge of technologies and techniques in order that they may be made 
more efficient and effective in governing the workplace. The workplace learning literature focuses broadly on constructing knowledge necessary to produce and guide practices of formal and informal learning. Thus, the work of the technologies or techniques which diffuse the language of workplaces and are specific to particular settings and times are not necessarily considered as sites of learning or governance. Certainly the rhetorical tactics of the kinds of interaction that we have been exploring here are relatively unexamined. Analyses of power drawing on the work of Michel Foucault are focused on diagnosis (Rose 1999a), but tend to be directed as diagnosis at a relatively general level. They fail to examine in any great detail the empirical practices involved in differing sites, locations and at different times.

This latter literature (cf. Dean 1999; Rose 1999a) tends also to focus on the 'psy' and confessional technologies as key to the internalization and intensification of the exercise of power in contemporary societies. Mechanisms of governance are talked about in the workplace learning literature in terms of increasing managerialism in the workplace, audit and evaluation, performance appraisals, and the like. This ignores the potential for the critical investigation of practices of learning in their relation with those of the kinds of language interaction in the workplace that we have been exploring here, and with those of audit and evaluation, management and administration. It is not only the specifics of interaction, but the wider regime with which they are articulated that might be important to explore in understanding the relations of power.

The point of exploring the means by which governing takes place and its effects in this way is that we begin to see the detail of how human technologies are deployed and link up as assemblages for governing. There is potential for the identification of other forms for the exercise of power in practices of work and as learning. The work of Solomon et al. (2006) and Rooney and Solomon (2006) is significant here in exploring the work of metaphors and spaces for learning in this way. Confessional technologies and their related tactics, as we see also here, are not the only ones at work in workplaces. Technologies for the activation of workers are deployed variously. They differ in different contexts and are of diverse form. Their detailed exploration and theorization may be important if we are to understand these links and relationships, and thus the varied means by which activation takes place and various effects and dispersions of these in activating workers.

Thus, through the analysis as conducted in this article, we get a better understanding of how policies promoting the ideal of the active worker may become joined up in assemblages that take discursive effect in local work sites, contributing to debates on forms of governance, worker subjectivity, professionalization and workplace learning in our times. This is not to suggest that subjectivities are determined through technologies and mechanisms of governance or policy. There are always possibilities for alternative forms, activities and refusals. And it is important to remember that the kind of theorization that we have produced here is also already bound up in those mechanisms for the exercise of power, not the least those of rhetoric, that it explores through this narration (Nicoll 2008). However, to retain the possibility of refusal, or at least increase the contestability of forms or mechanisms of governance including those that produce and interrogate forms of workplace learning, requires a form of investigation that can 'map the horizons of our thought and think beyond them' (Rose 1999a, p. 59). This article has been an attempt to do so.

\section{Acknowledgements}

The research on which this article is based was made possible by a grant from the Swedish Research Council. 


\section{References}

Andersen, N.A. and A. Born 2008. The employee in the sign of love. Culture and Organization 14, no. 4: 325-43.

Barratt, E. 2002. Foucault, Foucauldianism and human resource management'. Personnel Review 31, no. 2: 189-204.

Barratt, E. 2003. Foucault, HRM and the ethos of the critical management scholar. Journal of Management Studies 40, no. 5: 1069-87.

Barratt, E. 2008. The later Foucault in organization and management studies. Human Relations 61, no. 4 515-37.

Boud, D., Cressey, P. and P. Docherty, eds. 2006. Productive reflection at work: Learning for changing organizations. London: Routledge.

Boud, D. and J. Garrick, eds. 1999. Understanding learning at work. London: Routledge.

Collinson, D.L. 2003. Identities and insecurities: Selves at work. Organization 10, no. 3: $527-$ 547.

Dahl, H.M. (2009) New Public Management, care and struggles about recognition. Critical Social Policy 29, no. 4: 634-54.

Dahlstedt, M. 2009. Aktiveringens politik: Demokrati och medborgarskap för ett nytt millennium. Malmö: Liber.

Dean, M. 1999. Governmentality: Power and rule in modern society. London: Sage.

du Gay, P. 1995. Consumption and identity at work. London: Sage.

Dreyfus, H. and P. Rabinow 1982. Michel Foucault: Beyond Structuralism and Hermeneutics. New York: Harvester Wheatsheaf.

Edwards, R., Nicoll, K., Solomon, N. and R. Usher 2004. Rhetoric and educational discourse: persuasive texts? London: Routledge.

Ellström, E., Ekholm B and P-E Ellström 2008. Two types of learning environment: Enabling and constraining a study of care work', Journal of Workplace Learning, 20(2): 84-97.

European Commission. 2001 Communication from the Commission: Making a European area of lifelong learning a reality. Brussels: European Commission.

Entwistle, T., Marinetto, M. and R. Ashworth 2007. Introduction: New labour, the new publicc management and changing forms of human resource management. International journal of human resource management 18, no. 9: 1569-74.

Fejes, A. 2008. Governing nursing through reflection: a discourse analysis of reflective practices. Journal of Advanced Nursing 64, no. 3: 243-50.

Fejes, A. 2010a. Discourses on employability: Constituting the responsible citizen. Studies in continuing education 32, no. 2: 89-102.

Fejes, A. 2010b Confession, in-service training and reflective practices. British Educational Research Journal. First published on: 21 July 2010 (iFirst) DOI: $10.1080 / 01411926.2010 .500371$

Fejes A., and K. Nicoll, eds. 2008. Foucault and lifelong learning: Governing the subject. London: Routledge.

Fejes, A. and K. Nicoll, K. 2010. A "vocational calling": Exploring a caring technology in elderly care. Pedagogy, Culture \& Society18, no. 3: 352-370.

Foucault, M. 2007. Security, territory, population: Lectures at the Collège de France 19771978. Houndmills: Palgrave MacMillan.

Hammersley, M. and P. Atkinson 1995. Ethnography: Principles in Action. London: Routledge.

Hebson, G., Grimshaw, D. and M. Marchington 2003. PPPs and the changing public sector ethos: case-study evidence from health and local authority sectors. Work, Employment \& Society 17, no. 3: 481-501. 
Henriksson, L. 2010. Human service labour force in the making: Spotlight on Finnish practical nurses, In Learning and work and the politics of working life: Global transformations and collective identities in teaching, nursing and social work, eds. T. Seddon, L. Henriksson and B. Niemeyer, 33-50. London: Routledge.

Hollway, W. 2001. Gender difference and the production of subjectivity, In Discourse theory and practice: A reader, eds. M. Wetherell, S. Taylor and S.J. Yates, 272-283. London: Sage.

Johns, C. (2000) Becoming a reflective practitioner. Oxford: Blackwell Publishing

Knights, D. and D. McCabe 2003. Governing through teamwork: Reconstituting subjectivity in a call centre. Journal of Management Studies 40, no. 7: 1587-619.

Kubiak, C. 2010. Paraprofessional development in the UK, In Learning and work and the politics of working life: Global transformations and collective identities in teaching, nursing and social work, eds. T. Seddon, L. Henriksson and B. Niemeyer, 125-141. London: Routledge.

Metcalfe, A.W. 1992. The curriculum vitae: Confessions of a wage-labourer'. Work, Employment \& Society 6: 619-41.

Ministry of Social Affairs. 2007. SOU 2007:88: Att lära nära: Stöd till kommuner för verksamhetsnära kompetensutveckling inom omsorg och vård av äldre. Stockholm: Regeringskansliet.

Nicoll, K. 2008. Flexibility and Lifelong Learning: Policy, discourse and politics. $2^{\text {nd }}$ edn. London: Routledge.

Potter, J. 1996. Representing Reality: Discourses, Rhetoric and Social Construction. London: Sage.

Rooney, D.L. and N. Solomon. 2006. Consuming metaphors: stimulating questions for everyday learning. Studies in the Education of Adults 38, no. 1: 64-73.

Rose, N. 1996. Inventing ourselves: psychology, power and personhood. Cambridge: Cambridge University Press.

Rose, N. 1999a. Powers of Freedom: Reframing Political Thought. Cambridge: Cambridge University Press.

Rose, N. 1999b. Governing the soul: The shaping of the private self. London: Free association books.

Sewell, G. 2005. Doing what comes naturally? Why we need a practical ethics of teamwork. International journal of human resource management 16, no. 2: 202-18.

Solomon, N, Boud, D. and D. L. Rooney. 2006, The in-between: exposing everyday learning at work. International Journal of Lifelong Education 25, no. 1:3-15.

Theodisius, C. 2008 Emotional labour in health care: The unmanaged heart of nursing. London: Routledge.

Thomas, R. and A. Davies. 2005. Theorizing the micro-politics of resistance: New Public Management and managerial identities in the UK public services. Organization Studies 26, no. 5: 683-706.

Townley, B. 1993a. Performance appraisal and the emergence of management. Journal of Management Studies 30, no. 2: 221-38.

Townley, B. 1993b. Foucault, power/knowledge, and its relevance for human resource management. Academy of management review 18, no. 3: 518-45.

Townley, B. 1994. Reframing human resource management: Power, ethics and the subject at work. London: Sage.

Townley, B. 1996. Accounting in detail: accounting for individual performance. Critical Perspectives on Accounting 7: 565-84.

van Berkel, R. and V. Borghi. 2007. New modes of governance in activation policies. International Journal of Sociology and Social Policies 27, no. 7-8: 277-86. 